\title{
2
}

\section{The Ocean Perspective}

\author{
Kira Gee
}

\section{Introduction}

Who has known the ocean? Neither you nor I, with our earth-bound senses, know the foam and surge of the tide that beats over the crab hiding under the seaweed of his tide pool home; or the lilt of the long, slow swells of mid-ocean, where shoals of wandering fish prey and are preyed upon, and the dolphin breaks the waves to breathe the upper atmosphere. (...) To sense this world of waters known to the creatures of the sea we must shed our human perceptions of length and breadth and time and place, and enter vicariously into a universe of all-pervading water. For to the sea's children nothing is so important as the fluidity of their world. (Carson 1937)

In the Western world, as elsewhere, our human history is closely interwoven with the sea. Human relationships with the sea have been considered from angles as different as philosophy, geography, military studies, navigation and seafaring, natural sciences, political sciences, and social sciences and have featured in the various fields of art, literature, and music for centuries if not millennia. Planning is a relative newcomer in this long list of disciplines, bringing its very own perspectives and epistemologies. These in turn are driven-in part at least — by established notions such as the ability to delineate administrative

K. Gee $(\bowtie)$

Human Dimensions of Coastal Areas, Helmholtz Zentrum Geesthacht,

Geesthacht, Schleswig-Holstein, Germany

e-mail: kira.gee@gmx.de 
boundaries in the sea, as well as other perspectives that enable the sea to be subjected to a planning rationale in the first place.

How we think of the sea, and how we came to think of the sea in spatial planning terms, is the main focus of this chapter. It does not seek to present a comprehensive overview of man's relationship with the sea-this would be the subject of a book in its own right. Rather, it is selective in highlighting key perspectives that have developed over time and that still determine how we think of the ocean in our Western world-and I do emphasise that this is a Western perspective. Our ways of thinking about the sea influence how we choose to manage the ocean and what limits current approaches to management, and they are also important for understanding some of the conflicts this causes in marine management and governance today.

So what do we see when we look out to the sea? What do we mean when we say "ocean", and how are we in the Western world currently conceptualising the ocean? This chapter aims to draw out some fundamental lines of thought and show how these have shifted over time in response to certain driving forces. One perspective is that of differing attempts at understanding, delineating, and ultimately exploiting the ocean, leading to the duality between an industrial, exploitative perspective (often labelled "blue growth") on the one hand and the environmental perspective on the other. But oceans are also social spaces, communication spaces, and cultural spaces - and they play an important role in how we as humans understand ourselves as communities and individuals. The sections are in no particular order of importance. Section 2 outlines some of the fundamental challenges we have as humans in understanding a watery world so very different from our own. Section 3 discusses endeavours to enclose the ocean as part of nation's territory. Section 4 moves on to scientific attempts at making the ocean more amenable to exploitation, leading on to a discussion of some current policy lines within the European Union (EU) related to the oceans. Section 5 considers the ocean as an aesthetic and affective space. The chapter closes by offering some thoughts on what this might imply for maritime spatial planning (MSP).

\section{Grasping the Ungraspable}

Water is the cradle of philosophy, and according to Thales of Milet (around $600 \mathrm{BC}$ ), water is the cradle of all things. He considered the earth to float on water, and also saw water as the arche, the element and the first principle of existing things - in other words, the origin of all things to which all things must return. It has been suggested that Thales' philosophy may have been influenced by his life on the coast and first-hand observations of the ocean 
(Scholtz 2016), a fact which may also be true of another early philosopher and pupil of Thales, Anaximander, who came to consider water as the origin of life. In his philosophy, which was still founded on the idea of a first and allencompassing principle, water and earth produced fish through heat, and independent humans initially developed in these fish-like beings-a transition that took place in the sea. Heraclitus (about 535-475 BC) was first to speak more specifically of the transition between the elements, encapsulated in the principle of "panta rhei", or everything flows, describing the idea that the cosmos itself is engaged in a permanent circular movement: earth becomes water, water becomes earth, and in this permanent transition and change, everything is in fact one. Heraclitus' world is like the sea, a world that never stands still yet one that is indestructible, often encapsulated in the phrase "noone steps in the same river twice". In some way, Heraclitus could be said to pre-empt a more modern take on the geography of the oceans, a view of the oceans as a "dynamic system that is perpetually being remade" (Steinberg 2014), or a system that is less an object but a constant state of becoming (Ryan 2012). Everyday language has also taken up metaphors of the sea to symbolise change, such as stemming the tide of something, a wave of innovation, or a flood of new ideas.

Building on these philosophical considerations, is it possible to approach the nature of the ocean more closely, from within so to speak? How can this exceptionally ungraspable space (Steinberg 2014, p. xvi) be grasped after all? In the same piece, Steinberg (2014) summarises some of the inherent difficulties we humans face when encountering and describing the ocean. One is that human ocean experiences are always indirect, requiring mediation by a range of tools, not least to enable some form of immersion in the water. As a result of these physical barriers, we can never truly be "of the ocean". The ocean must therefore be regarded as the "other", something that is not terra firma and something that is always to some degree unknowable. Seas and oceans thus become an object, "a substance, a surface of difference" in a land-ocean binary. Much of our human perception and representation, including artistic representation, has reproduced that difference-in science, for example, by restricting ourselves to analysing particular ocean uses, or the mobilities of species, or experiences of those gazing at the ocean, rather than looking at the entirety of experiences and the co-construction of the ocean by humans and the water itself. Another difficulty, also argued by Steinberg (2014), is that locations in the ocean are difficult to grasp. Maps and planning documents suggest a false sense of the static, obscuring the continuous movement of the water that makes it impossible to truly locate a point in the ocean as a permanent material place. Returning to Heraclitus at this point, the ocean is constant 


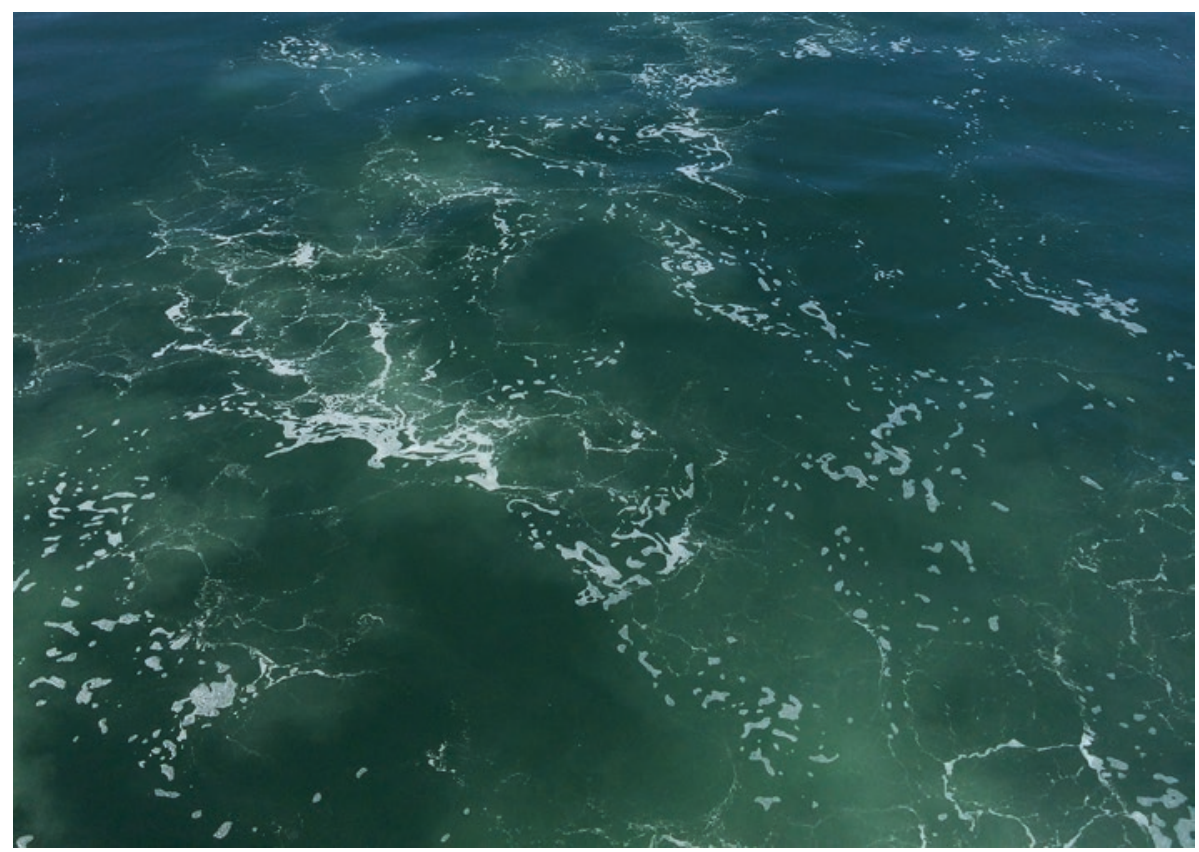

Fig. 2.1 The shifting sea? Photo: Kira Gee

flux-requiring us to re-think conceptions of ocean space in terms of both geophysical and social processes. This may also have implications for MSP: What are we actually able to locate and own in the sea? What kind of map do we require for doing so? And for what purpose? (Fig. 2.1).

\section{The Territorial Perspective}

\subsection{Mare Liberum and Mare Clausum}

The question of what can be localised in the sea is one that also arose around 1600 , in the context of a dispute concerning ownership in the sea. At that time, physical and moral perspectives of the sea were still interlinked (Scholtz 2016), and so the question of whether property was possible in the sea was inevitably also a moral one, touching upon the morality of law and freedom and early expressions of international law (see also Chap. 16 in this volume).

The discussion began with a dispute over who ruled the sea routes from Europe to India. Exploration had become common at the time and mainly served the acquisition of property, both in terms of tradable goods such as 
spices and in terms of territory which was colonised and appropriated by subjugating the indigenous peoples. This gave rise to new forms of conflict and competition, and when the Portuguese claimed sole user rights of the trade routes to India, the Netherlands protested. Mare Liberum, or "The Free Sea", was written in 1609 by Hugo Grotius, a Dutch jurist and philosopher, in defence of the idea that the sea belonged to all. Grotius is known as one of the fathers of international law, but his argument is based on natural law, which he considered of universal validity (Scholtz 2016).

Natural law is based on the assumption that God, or nature, has given Earth to all of humankind as common property. Private property is considered necessary as some things can be consumed, or only be used by one person at a time, and are therefore no longer available to others. Early property rights to land and livestock, for example, are based on this idea, as is collective or public property, in the sense that something can become the property of a particular community at the exclusion of other people. Both are distinct from common property which belongs to all of humankind. In order to find recognition as private or public property, certain conditions must be met. Movable goods, for example, need to be explicitly appropriated, and non-moveable goods such as land must be delineated, built on, or guarded to indicate their appropriation.

Grotius argues that private or public ownership of the sea is impossible as well as immoral. In a distinction that is carried over in today's international law of the sea, he contends that resources such as fish may be appropriated but that the sea itself as an immeasurable good does not allow its possession. Four arguments stand out in making this case. Firstly, Grotius contends that private property is only possible for things in which one has a personal interest. Fishers, for example, are interested in fish and might want to protect their catch from rivals, but they do not need to protect the sea itself as there is always enough of the sea for others to also fish (Tuck 1999). Secondly, he argues, it is a fundamental right of all private individuals to acquire goods and protect them, as long as this does not take away the legitimate goods of another person - another argument related to the boundless nature of the sea. Thirdly, trade is an essential means of sharing wealth and facilitating the just distribution of goods in the world. Oceans and winds enable trade over long distances, but free trade demands free seas, and anyone enclosing the sea for the purpose of owning it, and thereby restricting the freedom of others, would commit an injustice (Scholtz 2016). In the dispute over ownership of the trade routes' access to East India, Grotius therefore contended that the Dutch had a fundamental right to seek trade in the East Indies and that Portuguese attempts at preventing this could only be legitimate if they could claim 
ownership of the seas - which clearly they could not (Tuck 1999). The fourth, and perhaps most interesting, argument is that the innate nature of the sea itself prevents it from being privately or publicly owned. Because it is fluid, it cannot be possessed in the sense of being demarcated as an object or property. It cannot be bought or sold or divided up through contracts. The sea "wants" to serve everyone, and it can do just that because it is apparently inexhaustible and not used up by any particular activities or-at the time of Grotius at least—not damaged by human use.

All that which has been so constituted by nature that though serving some one person it still suffices for the common use of all other persons, is to day and ought to remain in the same condition as when it was first created by nature. (...) The air belongs to this class of things for two reasons. First, it is not susceptible of occupation; and second its common use is destined for all men. For the same reasons the sea is common to all, because it is so limitless that it cannot become a possession of any one, and because it is adapted for the use of all, whether we consider it from the point of view of navigation or of fisheries. (Grotius 1609/1916 translation)

The particular nature of the sea is encapsulated in the following paragraph:

(...) the question at issue is the outer sea, the ocean that expanse of water which antiquity describes as the immense, the infinite, bounded only by the heavens, parent of all things; the ocean which the ancients believed was perpetually supplied with water not only by fountains, rivers, and seas, but by the clouds, and by the very stars of heaven themselves; the ocean which, although surrounding this earth, the home of the human race, with the ebb and flow of its tides, can be neither seized nor inclosed; nay, which rather possesses the earth than is by it possessed. (ibid.)

This also points to a distinction between the seashore and inner sea and the outer sea. Grotius contends that the shore and inner seas can be occupied and used and therefore considered public property, but even there the sea is an agent that cannot be contained:

[The shore] becomes therefore the property of the occupier, but his ownership lasts no longer than his occupation lasts, inasmuch as the sea seems by nature to resist ownership. For just as a wild animal, if it shall have escaped and thus recovered its natural liberty, is no longer the property of its captor, so also the sea may recover its possession of the shore. (ibid.) 
But freedom of the seas also requires that the freedom of everyone else is respected. Thus, Grotius also acknowledges that there must be laws and limits to what is permitted at sea. Protection and jurisdiction, however, are set apart from ownership, and there is a clear statement that fleets maintained for the protection of navigation or the punishment of pirates under a certain jurisdiction do not then lead to ownership of the sea:

We recognize, however, that certain peoples have agreed that pirates captured in this or in that part of the sea should come under the jurisdiction of this state or of that, and further that certain convenient limits of distinct jurisdiction have been apportioned on the sea. Now, this agreement does bind those who are parties to it, but it has no binding force on other nations, nor does it make the delimited area of the sea the private property of any one. It merely constitutes a personal right between contracting parties. (ibid.)

This last aspect is important as it recognises realities such as piracy, which did threaten this rather idyllic picture. The sea, of course, was a stage for nations to compete for influence and territory, and England was only able to become a global power thanks to its ability to control the sea. In line with the desire for hegemony, in 1635, the Englishman John Selden developed the opposing doctrine of "mare clausum", reaffirming what had become standard practice based on the accepted notion that states have jurisdiction over their neighbouring waters. Although jurisdiction did not allow them to ban fishing and sailing in these waters, it did permit them to introduce regulations that effectively resulted in the same (Tuck 1999). Mare clausum thus amounted to a division of the sea into national spheres of interest, to the exclusion of other states (Ratter 2018). To some degree, this argument was based on the rights of states to national security and their ability to restrict a certain sea area to other states. The point of contention then became what stretch of water could reasonably be controlled by a coastal state. Arguably, the range of the most advanced cannon at around 1700 was three nautical miles, the birth of the $3 \mathrm{~nm}$ zone (Ratter 2018).

\subsection{UNCLOS: A History of Enclosure?}

International maritime law evolved in an ongoing compromise between the principle of freedom of the seas for navigation and resource management for the allocation of exploitation rights (Portman 2016). In the past, distances and the limited ability to travel had effectively created spatial monopolies over 
resources. In the early twentieth century, some nations expressed their desire to extend national claims, for example, to include mineral resources, to protect fish stocks, and to enforce pollution controls. In 1945, in an interpretation of the principle of a nation's customary right to protect its natural resources, President Truman extended US-American control to all the natural resources of the US continental shelf (Ratter 2018; Portman 2016). Similar claims quickly became standard practice. By 1967, only 25 nations still used the old 3-mile limit; many more had set a 12-nautical-mile territorial limit and eight had even set a 200-nautical-mile limit. By that point, national sovereignty was no longer a question of expressing and exercising power as a physical presence: Annexing maritime areas became a matter of simply staking a national claim, either in line with or even disregarding international guidelines (Ratter 2018).

The United Nations Convention on the Law of the Sea (UNCLOS) began to be negotiated in the 1950s. The first round of negotiations led to the Convention on the Territorial Sea and the Contiguous Zone, the Convention on the Continental Shelf, and the Convention on the High Seas (all 1958). Nevertheless, nations continued to make varying claims of territorial waters, and so the Third United Nations Conference on the Law of the Sea was convened in New York in 1973 to set limits, to agree on navigation, archipelagic status, and transit regimes, as well as set out exclusive economic zones (EEZs) and continental shelf jurisdiction. Countries now have sovereignty over their internal waters and territorial seas up to $12 \mathrm{sm}$, sovereign rights in the EEZs to conduct certain activities, and the rights to exploit certain resources of the continental shelf. But apart from defining ocean boundaries and associated rights, the convention also establishes general obligations for safeguarding the marine environment and protecting freedom of scientific research on the high seas (Portman 2016).

In areas beyond national jurisdiction, the principle of a "common heritage of mankind" was introduced, ensuring that no state is able to claim or exercise sovereignty or sovereign rights over any part of these sea areas (see also Chap. 16 in this volume). Consciously or unconsciously, this reaffirms Grotius' legal and moral notion of the sea as common property: "All rights in the resources of the Area are vested in mankind as a whole" (UNCLOS Art. 137). Buoyed perhaps by the spirit of the times and the idea of a more equitable distribution of global wealth, Article 140 goes on to specify that "Activities in the Area ${ }^{1}$

${ }^{1}$ Area beyond national jurisdiction. 
shall, as specifically provided for in this Part, be carried out for the benefit of mankind as a whole, irrespective of the geographical location of States".

The self-interest of countries to have exclusive fishing rights and rights over other resources, however, soon trumped any burgeoning international ideals. Countries began to demarcate areas according to the newly agreed extensions, in some cases resulting in huge territorial gains. Countries are continuing to extend their jurisdictional authority seawards, mainly by invoking an UNCLOS provision which allows coastal states to establish the outer edge of the continental margin up to $350 \mathrm{~nm}$ wherever the margin extends beyond 200 nautical miles. At the same time, special transit rights apply in the case of straits and also for land-locked states.

So where will it all end? In the face of ongoing and prospective disputes over marine resources such as the Arctic, the question of who can claim property in the sea remains a highly pertinent one. Despite the noble intentions encapsulated in the idea of a common heritage of mankind, UNCLOS has effectively condoned a veritable race between coastal states to carve up the ocean-racing to secure resources and therefore also political and economic power in a rapidly changing world. It has created wholly new maps of the world and led to new theatres of conflict (Ratter 2018). The trend to increasing territorialisation of the sea is inextricably linked to the increasing industrialisation of marine resource exploitation (Vitzthum 1981), enabling countries to go faster and deeper and becoming ever more efficient in extracting resources from the sea. Some authors have compared this to the colonisation of continents in earlier periods - with a clear advantage to those countries that have a coast or islands and are wealthy already and can afford the expensive technology.

The key question — not least for MSP — is whether some degree of ownership, or at least custodianship of sea areas, is able to prevent a tragedy of the commons (see also Chap. 5 in this volume). This will depend on whether exercising jurisdiction over natural resources is also taken to mean responsibility for their conservation, leading to prudent utilisation. The alternative development path may be unlimited "ocean grabbing" in an environment that still lacks a comprehensive approach to governance (Portman 2016). Are the current rules that guide exploitation sufficient, and who polices them? And what really is our attitude to the conservation of the ocean: Does this offer an alternative trajectory? 


\section{Scientific Discovery and Ocean Resources}

\subsection{Changing Relations with the Ocean in the Wake of Discovery}

Despite the many dangers associated with it, the obvious "otherness" of the ocean has not stopped humans from being curious about it. Until the last quarter of the eighteenth century, European understanding of the ocean's depth derived mostly from the imagination, based on stories recorded in ancient literature and the Bible. In the late eighteenth and nineteenth century, this changed as a result of technological advances and a growing interest in natural sciences, as well as a burgeoning interest in the ocean as a place. An important shift took place at this time, a re-interpretation of the ocean as a desirable place rather than a barrier to overcome (Rozwadowski 2005).

The changing Western relations with the ocean during this period are down to a confluence of factors. Of particular importance is the coming together of the expansionist tendencies of the great maritime nations of the time, Britain and the USA, and the growing interest in and capability of scientific exploration. Ocean resources, and the economic benefits associated with them, were highly desirable in a time of international competition, and in particular in the USA there was a strong link between commercial maritime interests and early scientific institutions such as the Coast Survey (Rozwadowski 2005). Discovering and understanding ocean resources required systematic scientific investigation of ocean places, and locating them in the vastness of the ocean required new kinds of maps. But although perceptions of the sea were still driven by ambitions for using its resources, the ocean increasingly became an object of investigation in itself.

In terms of getting to know the ocean, two approaches became predominant in the eighteenth century: hydrography and natural sciences. Both were preoccupied with the deep sea, albeit for different reasons. Charting the ocean floor and arriving at a bathymetric chart of ocean areas was related to navigational safety but also to early commercial endeavours such as attempts to lay the first submarine cable between the USA and Britain. But there was also growing interest in a physical geography of the sea as such, in order to understand the physical phenomena of the sea. The first bathymetric charts and vertical elevation profiles of large parts of the Atlantic appeared in the midnineteenth century based on deep-sea sounding programmes. Hydrographic exploration and exploitation stimulated each other, bringing together the natural curiosity and spirit of the early oceanographers, the financial might of 
investors and companies, and the political interest and naval capability of seafaring nations. As oceanography developed, early, more holistic approaches were gradually replaced by mathematical analysis. Thus the oceans "came to be seen not as trackless wastes (the view of ancient and classical authors), nor as part of a great interlinked cosmic machine (Humboldt's view in the early nineteenth century) but as physical phenomena subject to mathematical analysis" (Mills 2009, p. 10)—a view that still predominates today.

The natural sciences were also interested in the deep sea, driven mainly by the question of what creatures existed in the ocean and whether life was possible at all at great depth. As was the case for hydrography, two interests combined. Commercial interests mainly related to fish and whales as key resources-whose exploitation had grown exponentially due to better equipment and economic interest-but there was also the innate desire of science to learn more about marine life and its interconnections. Technological advances such as the advent of microscopes had led to recognition of the abundance and variety of life in the sea, and faced with this great and infinite life force, the response at the time was one of wonder. In his famous "Cosmos", published in 1845, the great polymath Alexander von Humboldt gives rather poetic descriptions of the ocean (Fig. 2.2):

The application of the microscope increases, in the most striking manner, our impression of the rich luxuriance of animal life in the ocean, and reveals to the astonished senses a consciousness of the universality of life. In the oceanic depths, far exceeding the height of our loftiest mountain chains, every stratum of water is animated with polygastric sea-worms, Cyclidiæ and Ophrydinæ. The waters swarm with countless hosts of small luminiferous animalcules, Mammaria (of the order of Acalephæ), Crustacea, Peridinea, and circling Nereides, which when attracted to the surface by peculiar meteorological conditions, convert every wave into a foaming band of flashing light. (Cosmos 1845, p. 305)

Although a more mechanistic perspective also began to emerge, there was no initial contradiction between the desire to understand, collect, and classify individual species and a holistic view of nature. This interest in collecting specimen was not restricted to scientists but extended to the population at large; shell collecting and marine aquaria for example became favourite Victorian pastimes in Britain (Rozwadowski 2005). As the available knowledge grew, sea monsters were gradually replaced with scientific evidence of life in the ocean, and blank areas on ocean charts were gradually filled, often resorting to the local knowledge of sailors and whalers regarding the distribution and geographical range of species. 


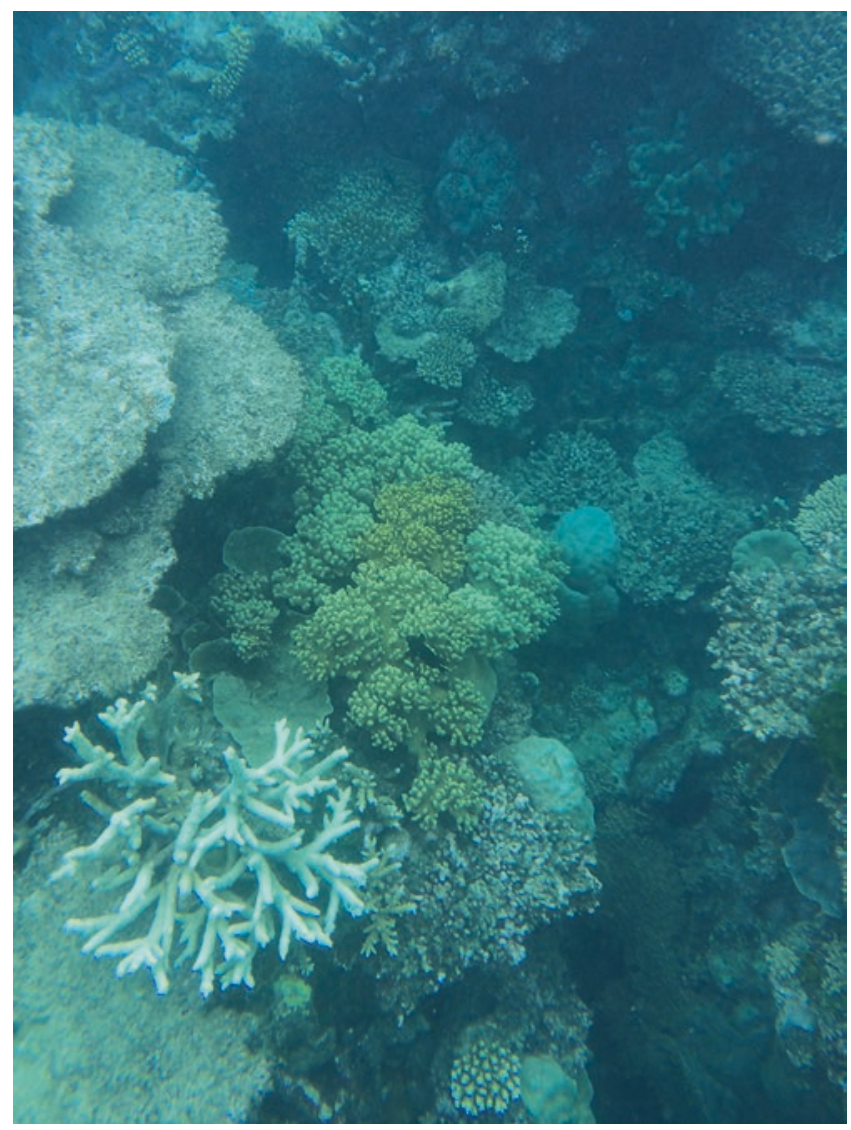

Fig. 2.2 The living sea? Photo: Kira Gee

Overall, the scientific approach has thus been one of mapping and structuring the ocean. Gradually, ocean space was placed, delimited, and sounded, and its material and spatial properties began to be understood in ever greater detail. This led to an expansion of the utilitarian relationship with the sea, not only through fishing and whaling but also, for example, seaside holidays. As technology improved, greater attention could be placed on ocean resources (Laloë 2016), a trend which is still ongoing today, for example, with oil exploration in the Arctic. The means available to exploration today have changed dramatically: Two-dimensional perspectives of the ocean have come to be replaced with three-, four- and even five-dimensional approaches (including the air above the sea and the substrate) made possible through filming and diving, opening up entirely new perspectives of the sea. Understanding connections has brought much greater awareness of the significance of the ocean 
to humankind as a whole, not least in the recent context of climate change. Last but not least, new technologies of exploring the deep have also brought about a new sense of wonder at the diversity and beauty of life in the ocean, evidenced for example by the popularity of documentaries such as the BBC's "Blue planet" series.

\subsection{Non-utilitarian Perspectives}

At the same time, there is also greater awareness of the fragility of the oceanpushed in recent times by issues such as overfishing, pollution, invasive species, and lately microplastics. The seemingly inexhaustible ocean resources first began to appear finite in the nineteenth century in the wake of more efficient and larger-scale exploitation. A new type of ownership of ocean resources had arisen contrary to Grotius' ideas, and it was clearly damaging to the interests of others who would also have a legitimate interest in these same resources. Social and moral criticism had also begun of industrialisation in general, as it became apparent that it not only produces human poverty but also impoverished, damaged nature (Scholtz 2016). The more human intervention changed nature, the greater the need became to account for and guide human action. Also, the more the knowledge was gained of the sea, and the greater the understanding of its diversity and wonder, the more pronounced the application of non-utilitarian thought in conceptions of the sea.

Bioethics-understood here to describe the relationship between the biosphere and a growing human population (Potter 1971) — is concerned with a responsible human relationship with nature and arose out of an expectation of nature that goes beyond economic benefits and utilitarian value. Two perspectives come together here. The first is the notion of nature's intrinsic value, in other words, the value possessed by things or organisms in and of themselves. The ocean is mostly valued instrumentally, that is, for the benefits associated with it - recreation, traditional fishing, an aesthetically pleasing view-but it could equally be valued as an entity all in itself, a carrier of value independent of any human observer. The second perspective recognises the need for rules in order to limit human intervention and reverse further damage. This can arise from a utilitarian argument and the idea that the sea gives pleasure and contributes to our welfare, but also from the idea of intrinsic value of nature, protecting nature for its own sake. The conviction that nature conservation is morally good, and that untouched nature should continue to exist, is quite prevalent in Western countries, in particular Germany (Gee 2013), first emerging in the 1970 s when resource shortages and environmental degradation led to the rise of 
environmentalism (Jepson and Canney 2003). Certain moral values serve as action guides here, i.e. a shared feeling that we (as individuals in a society) "ought" to behave in a certain way (Rokeach 1973).

Environmental protection has become an important focus of international coastal and ocean policy, driven by the many transboundary and global threats to the marine environment (Portman 2016). UNCLOS is one of the first such international agreements, although it could be argued that nations are more concerned with pushing through their national interests and are forgetting the obligations towards marine resources that also come with it. Despite the rise of sustainability as a unifying concept, there is still a divide between the desire to protect ocean resources on the one hand and facilitating their exploitation on the other (Portman 2016). Contradictory policy objectives are making it difficult to come to a unified guide to human action. This is amply illustrated in the EU's maritime policy (see also Chap. 6 in this volume). Although integration has become a central theme in maritime policy, discussions are ongoing in 2018 on how the demands of blue growth can best be reconciled with environmental protection and conservation.

\subsection{Contradictory Policy Goals: Can They Be Reconciled?}

In the early 2000s, the EU's incipient maritime policy was strongly influenced by the global economic crisis, the need for the EU to position itself against other powers such as China, and the difficult socio-economic situation in many EU member states. One of the first steps was the 2006 Green Paper "A Future Maritime Policy for the Union: A European Vision of the Oceans and Seas" (EC 2006) which describes the importance of oceans for innovation and cites geography as a reason for Europe's special relationship with the sea. The purpose of the paper, however, is clearly economic, asserting that Europe must revitalise its economy and emphasising the role already played by European oceans. Holistic ocean management is seen as a new approach, designed to overcome the largely sectoral and fragmented policy-making of the past. In its strategic objectives for 2005-2009 the European Commission thus declares "the particular need for an all-embracing maritime policy aimed at developing a thriving maritime economy, in an environmentally sustainable manner" (EC 2005).

One of the key problems is that the new approach to holistic ocean governance was underpinned by two pillars: the Lisbon strategy for growth and better jobs (European Council 2000) and maintaining and improving the status of the resource on which all maritime activities depend. In 2007, the 
Commission followed up on the Green Paper by publishing the so-called Blue Book on Integrated Maritime Policy (IMP) (EC 2007). Essentially an economic policy, this seeks to coordinate relevant sectoral policies by promoting cross-cutting issues, including blue growth, marine data and knowledge, and MSP. Although it is also anchored in the Gothenburg agenda for sustainability, the IMP predominantly rests on the Lisbon agenda for growth and jobs and can therefore be understood as a bifurcation point, a point in time when the economic "blue growth" rationale becomes a dominant discourse and branches off from the concurrent development of the environmental pillar and its central paradigm of Good Environmental Status (GES). Still, the IMP does point to the need to achieve the full economic potential of the seas in harmony with the marine environment, and thus also offers an anchor for environmental policy, in the sense that the IMP cannot be fully achieved without also achieving environmental objectives.

The Commission's economic priorities have since been reaffirmed repeatedly, such as the communication on Blue Growth Opportunities for Marine and Maritime Sustainable Growth (EC 2012) and Innovation in the Blue Economy: Realising the Potential of Our Seas and Oceans for Jobs and Growth (EC 2014) (see Chap. 6 in this volume). In parallel, the Marine Strategy Framework Directive (MSFD), adopted in 2008 (EC 2008), presents a "comprehensive and integrated approach to the protection of all European coasts and marine waters". ${ }^{2}$ The main aim of the MSFD is to achieve GES of the EU's marine waters. The main reason for this is instrumental, as the main purpose for doing so is to protect the resource base upon which economic and social activities depend. The ecosystem approach is presented as the guiding principle, although there is no clear definition of how this should be understood and implemented. Numerous other communications followed, mostly concerned with the implementation of the MSFD.

The concept of ecosystem-based management—along with its complementary principle, the precautionary approach — continues to be ill-defined and thus a struggle for marine managers and policymakers. Can MSP act as a bridge between the environmental and economic policy objectives? And what of the social dimension, the all-important third pillar of sustainability (see also Chap. 8 in this volume)? Early indications are that European countries are taking rather different approaches to the ecosystem approach and that it is a strong guiding principle in MSP in only some countries.

${ }^{2}$ http://ec.europa.eu/environment/marine/eu-coast-and-marine-policy/index_en.htm, accessed 8 March 2018. 


\section{$5 \quad$ Human Dimensions of the Ocean: The Ocean as a Place of Attachment}

So far, this chapter has sought to draw out some of the prevalent ocean perspectives and their historical roots. Different attempts at perceiving, mapping, and categorising the ocean have been traced, starting with Hugo Grotius and UNCLOS as an approach to territorialise the ocean and following on with science and exploration as ways of understanding the physicality of the ocean and the ocean as an environment and resource. We have also seen that current maritime policy is divided into economic and environmental strands and that reconciliation seems difficult. A pervading theme throughout has been the presence of apparently opposing views - the enclosed versus the free sea or the utilitarian and non-utilitarian perspective of the ocean. It has also become clear that views of the ocean always reflect the general mood and world view of the time-such as the spirit of exploration in the nineteenth century or the era of discovery and trade in the seventeenth century.

This last section gives another ocean perspective, namely that of the ocean as a place as experienced and cherished by people. This builds on the idea that from a geographical perspective, there are fundamentally different ways of seeing the ocean. The first is the practice of regarding the ocean as a collection of material, tangible entities, resulting in particular spaces composed of physical-material facts - such as ocean currents, water depth, water temperature, and flora and fauna. The second is the understanding of the ocean as a visual phenomenon, referring to the appearance of the ocean as we see it. The third-and the focus of this section — is the sea not as a space but as a placemoreover, a place that can generate deep-seated attachment and with this, care. Moving away from the idea of ocean space as an extension of terrestrial space and its associated "protocols of measuring and distributing surfaces" (Laloë 2016, p. 2), this perspective is perhaps least amenable to governance and potentially conflicting with a purely spatial and rational perspective reliant solely on physical data and scientific evidence.

\subsection{The Ocean as a Place}

The ocean as a place refers to deeper meanings and symbolisms, attachments and internal pictures of the sea we may hold. Perceptions of the sea have changed over the centuries in response to greater technological control, giving rise to an ambiguous image of the sea, appearing cold, inapproachable, and dangerous on the one hand yet representing summer, sun, and beach life on 
the other. Sea bathing and ocean going for pleasure became popular during the nineteenth century (Fischer and Hasse 2001), a "brief period of time when the sea held enough romance and mystery to fire the imagination but less threat than in previous centuries" (Rozwadowski 2005, p. 21). Maritime novels gained large followings and helped to create a rich popular imagination of the ocean, and there was increasing aesthetic appreciation of the ocean inspired by paintings of seascapes. The sea also became a place of reflection and transcendence, inspiring new experiences of the sublime-engendering a new sense of place of the ocean related to its purported health benefits, leisure, and aesthetic interests.

But is the sea in itself also a place or just an object to be gazed at from a distance? Relph (1976) noted that "every identifiable place has unique content and patterns of relationship that are expressed and endure in the spirit of place" (p. 76). Sense of place represents a combination of what could be termed "intrinsic personality" of the environment and the "emotional attachment to localities developed by individuals and communities in the course of living and growing within the setting of home" (Muir 1999, p. 273; Tuan 1975). In order to understand the values assigned to a place, it is therefore important to explore this emotional relationship of people with places. The greater the emotional involvement in a place, and the greater the meaning assigned to it, the greater the likelihood of strong attachment to the place and therefore value.

The relationship between sea and place is not an easy one to resolve. Since the sea is not dwelled in in the usual sense of the word, it is theoretically conceivable that the capacity of the sea to turn into a place is inherently limited. A more likely conclusion is that notions of place arise differently in the context of the sea. Global communication has arguably contributed to the demise of "space" in the sense that everywhere has long since become somewhere. But there is also a different, inherent sense of belonging to a home place, which extends to the sea just as much as it does to the land. A strong sense of belonging to the sea has been found in Irish and Scottish Gaelic fishing communities, described as "not so much a landscape, not a sense of geography alone, nor of history alone, but a formal order of experience in which all these are merged" (MacKinnon and Brennan 2012, p. 7). Those working with the sea carry a deeper way of knowing the sea which is distinct from more formal ways of knowing. MacKinnon \& Brennan find this reflected in the place names given to the sea by fishermen, indicative of a unique way of knowing the marine environment. This knowledge, they argue, represents a more complete way of knowing the sea than the objective precision of the natural sciences alone can deliver. This is because it also encompasses emotional energy as an indicator of "home" 
and a sense of responsibility for that home which is "place". Similar descriptions can be drawn from sailors describing emotional experiences of being on the water or other professional users of the sea or leisure users. The sea is thus just as much a place as the land, with subjectivity of place not only arising from direct use of the marine environment but also imagery and traditional knowledge. Especially in the context of immaterial or experiential conceptions of the ocean, there is no universal, tangible, physical reality but multiple ocean realities which can be appreciated for many different reasons (Fig. 2.3).

But how is meaning derived from the ocean? Essentially, this is a question of perception, understood here as different ways of experiencing and interpreting the ocean. Perception in turn is linked to the general values a person holds, as well as their general beliefs about the world at large and what is important in this world, which comes back to notions such as bioethics raised in the previous section.

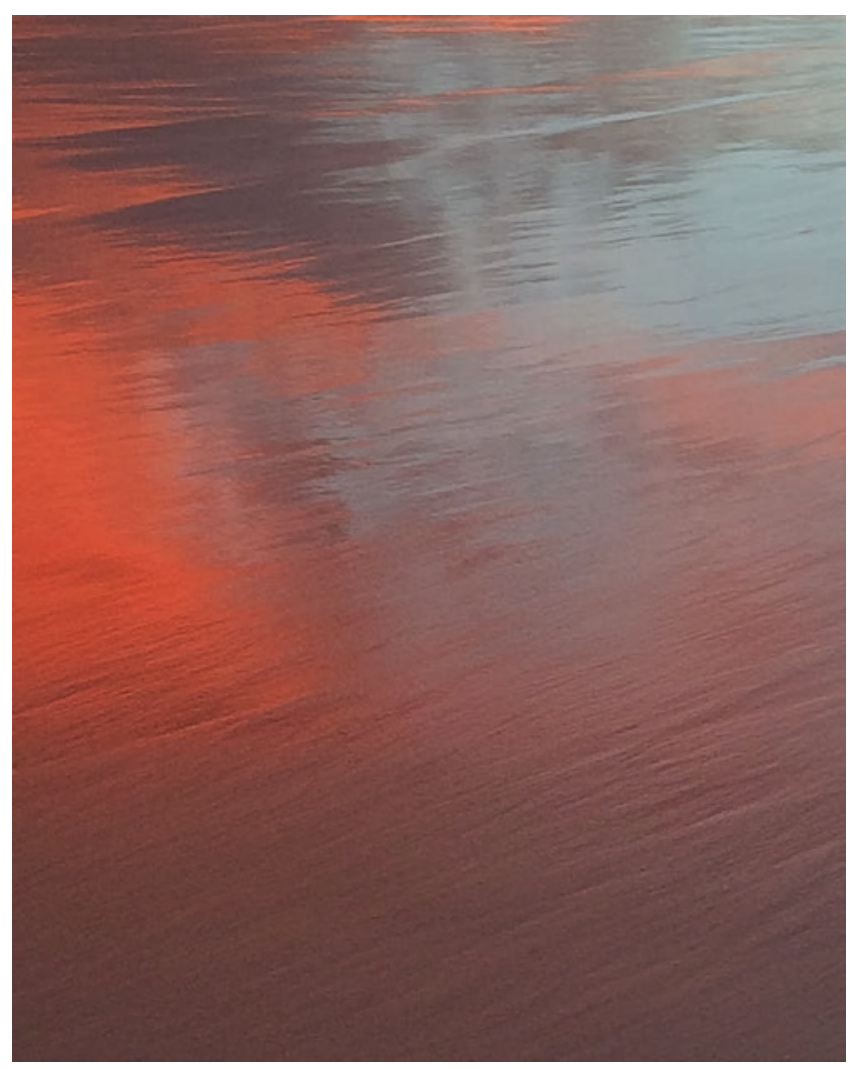

Fig. 2.3 The beautiful sea? Photo: Kira Gee 


\subsection{The Ocean as a Cultural Landscape?}

An interesting perspective with relevance for the perception of the ocean is a duality that is better known from landscape research, namely the dualism between natural and cultural landscapes. The common understanding is that natural landscapes are those uninfluenced by man, having grown from natural processes and still determined by natural processes, while cultural landscapes in the broadest sense are those that are shaped by man. Fischer (2007) describes the so-called dialectic of the Enlightenment whose opposing trends led to the conception and importantly, valuation of both types of landscape. The first of these trends is the re-evaluation of nature and a re-interpretation of wild and threatening landscapes as something pleasing and beautiful. The coast-and imaginably also the ocean-is a prime example of a place which was no longer seen as dangerous and a location of divine retribution but came to be regarded as "wilderness" and a sublime place. Wilderness, often defined as extreme landscape formations, was re-interpreted as something of great value; much later, this was to become the founding idea of National Parks. Today, the "natural" is still a by-word for that which is inherently good, desirable, and pure; it has become all the more desired the less immediate our connection to nature. "The longing of tourists for 'beautiful' or even 'wild' nature is fed by the unconscious assumption that the 'natural' is needed as a cure for the overcivilization of the world in which we live" (Fischer 2007, p. 3). The idea of wilderness is one that influences perceptions of the ocean and does appear to be the opposite to the idea of the ocean as an increasingly "industrial" landscape. The second trend that began during the Enlightenment is the transformation and re-interpretation of inhospitable terrain and "badlands" (e.g. heathland, floodplains) into something that represented progress, therefore also becoming inherently good but for different reasons. Cultural landscapes became appreciated for the fact that they were man-made; as an added benefit (which may or may not be transferrable to the sea) they were regarded as aesthetically pleasing. Natural and cultural landscapes are therefore both valued in their own right but for different reasons and based on different value setsan analogy that could readily apply to the ocean (Fig. 2.4).

Gazing out to the sea can give the impression that the sea is still very much a natural landscape, untouched as it seems by any human influences and nothing but an infinite expanse of water stretching to the horizon. Although it is no "dwelling place" in the usual sense of the word, the sea does have longstanding links to cultural practices such as fishing or trading. In recent years, cultural practices have become markedly more intense, expressed for example 


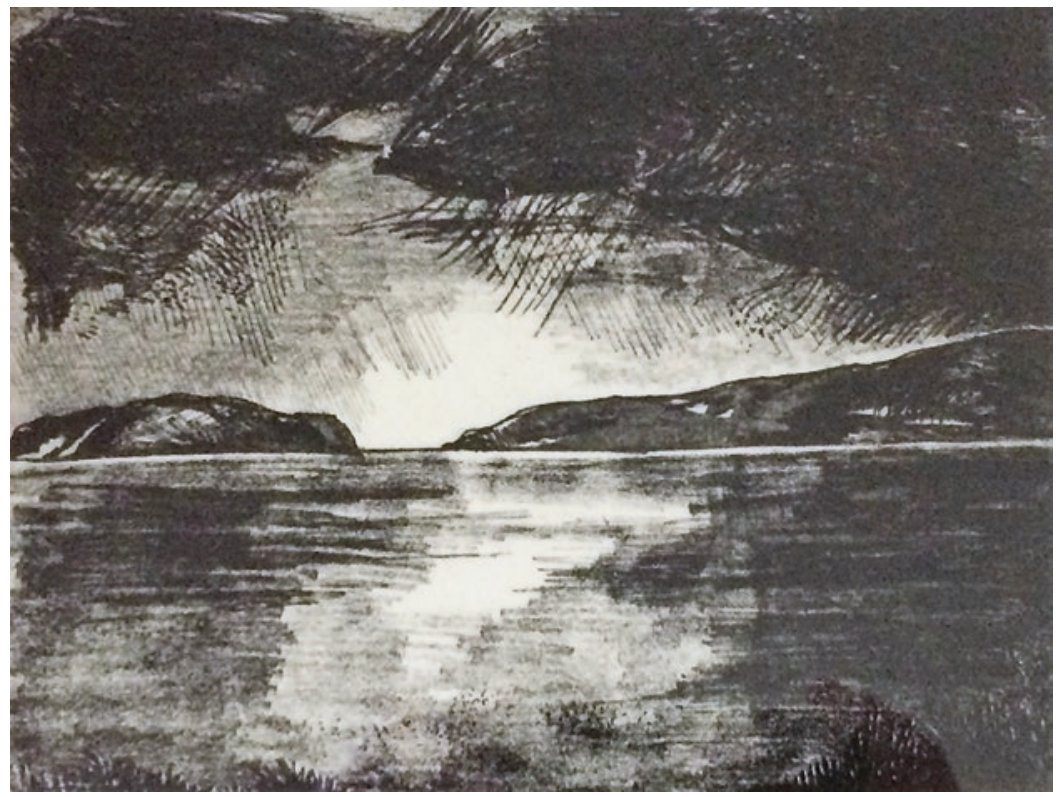

Fig. 2.4 The romantic sea? Etching: Kira Gee

in the growing numbers of vessels in the sea and the growing numbers of structures such as bridges, platforms, and off-shore wind farms. The visual alteration of the sea, the appearance of fixed structures in its infinite expanse, may suggest the sea is indeed becoming a "cultural seascape", shaped by man just like cultural landscapes on land. At the same time, it is unclear what would constitute a "natural seascape": A seascape that appears unaltered visually? An unpolluted sea? An ocean untouched by any human influence? An open question is also whether there is similar romanticism as far as the "untouched" sea is concerned, or whether some form of attachment may have developed to the new cultural seascape, regarding bridges or other structures-a symbol of development and progress for example. Could the dialectic of the Enlightenment be in the process of being repeated for the sea?

\section{Conclusion}

This chapter is a somewhat eclectic collection of ocean perspectives that have shaped our Western views of the ocean. I have attempted to trace the origins of some of our thinking and the conditions during which the pervading views first emerged. I have also attempted to highlight how these perspectives are reflected in ocean policy_or sometimes lack appropriate reflection. 
Naturally, the chapter cannot hope to capture the entire range of ocean perspectives and can rightly be criticised for being selective. For example, I have ignored some of the darker current perspectives, such as the role of the ocean as a barrier in the context of "fortress Europe". I have also ignored the role of the sea in military expansion, the changing role of the sea in times of climate change, or the fact that the sea can seem remote to people living a long distance from the coast. Many more perspectives could be listed here. What does become apparent, however, is the fact that ocean perspectives are as diverse and changeable as the ocean itself - and just as iridescent and fascinating in all their diversity. Oceans emerge as spatial metaphors and a way of structuring the perception of the social (Luutz 2007), much like regions that have come to be understood as produced by collective action (Paasi 1986). This implies the contingency of spatial entities and their disappearance when they are no longer reproduced by society.

The latter aspect in particular has implications for MSP. In the face of the many parallel constructs of the ocean and the many diverging roles the ocean plays in our society and subconscious, which ocean can and should we attempt to manage? Can diverging constructs of the sea as a transport space, fishing grounds, recreational space, natural habitat, or aesthetic place, plus the associated value sets and power relations, ever be brought together in a cohesive approach? Or will the ocean continue to remind us that attempts at management are temporary at best, that "panta rhei", everything, including philosophies of management, is in constant flux?

Acknowledgements This work was supported by the BONUS BALTSPACE project which has received funding from BONUS (Art 185) funded jointly from the EU's Seventh Programme for research, technological development, and demonstration and from Baltic Sea national funding institutions. The Open Access fee of this chapter was provided by the same project.

\section{References}

Carson, R. (1937). Undersea. Atlantic Monthly, 78, 55-67.

EC. (2005). Strategic Objectives 2005 - 2009: Europe 2010: A Partnership for European Renewal Prosperity, Solidarity and Security. Communication from the President in agreement with Vice-President Wallström. Brussels, 26.1.2005, $\operatorname{COM}(2005) 12$ final.

EC. (2006). Commission Green Paper: Towards a Future Maritime Policy for the

Union: A European Vision for the Oceans and Seas. COM (2006) 275 final. 
EC. (2007). An Integrated Maritime Policy for the European Union. Brussels, 10.10.2007, COM(2007) 575 final.

EC. (2008). Directive 2008/56/EC of the European Parliament and of the Council, of 17 June 2008, Establishing a Framework for Community Action in the Field of Marine Environmental Policy (Marine Strategy Framework Directive).

EC. (2012). Blue Growth Opportunities for Marine and Maritime Sustainable Growth. Brussels, 13.9.2012, COM(2012) 494 final.

EC. (2014). Innovation in the Blue Economy: Realising the Potential of Our Seas and Oceans for Jobs and Growth. Brussels, 13.05.2014, COM/2014/0254 final/2*.

European Council. (2000). Lisbon European Council, March, 23-24. Presidency Conclusions.

Fischer, L. (2007). Cultural Landscape and a Natural Landscape-Notes with Regard to the Wadden Sea Region. Presentation at the LanceWadPlan Final Conference, Wilhelmshaven, June 19. Retrieved from http://www.lancewad.org.

Fischer, L., \& Hasse, J. (2001). Historical and Current Perceptions of the Landscapes in the Wadden Sea Region. In: Vollmer, M., Guldberg, M., Maluck, M., Marrewijk, D. \& Schlicksbier, G. (eds). Landscape and Cultural Heritage in the Wadden Sea Region - Project Report, pp. 72-97.

Gee, K. (2013). Trade-Offs Between Seascape and Offshore Wind Farming Values: An Analysis of Local Opinions Based on a Cognitive Belief Framework. PhD dissertation, Department of Geography, University of Göttingen.

Grotius, H. (1916). The Free Sea (R. van Deman Magoffin, Trans.). New York: Oxford University Press.

Humboldt, A. (1845). Cosmos: A Sketch of the Physical Description of the Universe, Vol. 1 by Alexander von Humboldt, translated by E. C. Otte. from the 1858 Harper \& Brothers edition of Cosmos, volume 1. Retrieved from http://www.gutenberg. org/ebooks/14565.

Jepson, P., \& Canney, S. (2003). Values-Led Conservation. Global Ecology \& Biogeography, 12, 271-274.

Laloë, A. F. (2016). The Geography of the Ocean. Knowing the Ocean as a Space. Routledge.

Luutz, W. (2007). Vom “Containerraum” zur "entgrenzten” Welt-Raumbilder als sozialwissenschaftliche Leitbilder? Social Geography, 2(1), 29-45.

MacKinnon, I., \& Brennan, R. (2012). Belonging to the Sea. Exploring the Cultural Roots of Maritime Conflict on Gaelic Speaking Islands in Scotland and Ireland. Scottish Crofting Federation and Scottish Association for Marine Science.

Mills, E. (2009). The Fluid Envelope of Our Planet: How the Study of Ocean Currents Became a Science. Toronto: University of Toronto Press.

Muir, R. (1999). Approaches to Landscape. London: Macmillan Press.

Paasi, A. (1986). The Institutionalization of Regions: A Theoretical Framework for Understanding the Emergence of Regions and the Constitution of Regional Identity. Fennia, 46, 105-146. 
Portman, N. (2016). Environmental Planning for Oceans and Coasts: Methods, Tools, and Technologies. Springer International Publishing.

Potter, V. R. (1971). Bioethics: Bridge to the Future. Prentice-Hall.

Ratter, B. M. W. (2018). Geography of Small Islands. Outposts of Globalisation. Springer International Publishing.

Relph, E. (1976). Place and Placelessness. London: Pion.

Rokeach, M. (1973). The Nature of Human Values. The Free Press, Macmillan Publishing.

Rozwadowski, H. (2005). Fathoming the Ocean. The Discovery and Exploration of the Deep Sea. Cambridge, MA and London: The Belknap Press of Harvard University Press.

Ryan, A. (2012). Where Land Meets Sea. Coastal Explorations of Landscape, Representation and Spatial Experience. Routledge.

Scholtz, G. (2016). Die Philosophie des Meeres. mareverlag, Hamburg.

Steinberg, P. (2014). Foreword: On Thalassography. In J. Anderson \& K. Peters (Eds.), Water Worlds: Human Geographies of the Ocean (pp. xiii-xvii). Farnham: Ashgate.

Tuan, Y.-F. (1975). Place: An Experiential Perspective. Geographical Review, 65, $151-165$.

Tuck, R. (1999). Hugo Grotius. Reprinted in L. May \& M. McGill (Eds.). 2014. Grotius and Law. Routledge, pp. 37-68.

Vitzthum, W. G. (Ed.). (1981). Die Plünderung des Meeres-Ein gemeinsames Erbe wird zerstückelt. Fischer Taschenbuch Verlag, Band 4248.

Open Access This chapter is licensed under the terms of the Creative Commons Attribution 4.0 International License (http://creativecommons.org/licenses/by/4.0/), which permits use, sharing, adaptation, distribution and reproduction in any medium or format, as long as you give appropriate credit to the original author(s) and the source, provide a link to the Creative Commons licence and indicate if changes were made.

The images or other third party material in this chapter are included in the chapter's Creative Commons licence, unless indicated otherwise in a credit line to the material. If material is not included in the chapter's Creative Commons licence and your intended use is not permitted by statutory regulation or exceeds the permitted use, you will need to obtain permission directly from the copyright holder.

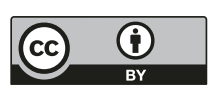

